\title{
Особливості формування озерного фітопланктону
}

\author{
Юлія Шелюк', Олена Житова², Наталя Курин ${ }^{1}$ \\ ${ }^{1}$ Житомирський державний університет імені Івана Франка, Житомир, Україна \\ ${ }^{2}$ Житомирський національний агроекологічний університет, Житомир, Україна \\ Адреса для листування: Shelyuk_Yulya@ukr.net
}

Отримано: 30.08.19; прийнято до друку: 20.10.19; опубліковано: 27.10.19

Резюме. Вперше проведено дослідження фітопланктону озер Воронки, Луко, Острівське (Рівненська область), Дідове і водно-болотного угіддя Горохівка (Житомирська область). Ідентифіковано 161 вид водоростей, представлений 165 внутрішньовидовими таксонами з номенклатурним типом виду включно, що належать до 84 родів, 48 родин, 28 порядків і 13 класів. Встановлено, що у формуванні озерного фітопланктону провідну роль відіграють діатомові і зелені водорості. Кількість таксонів рангом нижче роду достовірно корелює з $\mathrm{pH}$, кольоровістю і не залежить від площі озер. Виявлено тенденцію до посилення ролі дрібноклітинних центричних діатомових зі зростанням умісту фосфору фосфатів $\mathrm{i}$ загального азоту. Середнє значення діатомового коефіцієнта озер сягало 0,42.

Встановлено помірну залежність інтенсивності вегетації водоростей від температури води, вмісту фосфору фосфатів. Найсильніший вплив на інтенсивність його вегетації має $p H$ води, слабший температура води, вміст фосфору фосфатів та загального азоту. В досліджуваних озерах провідна роль належить планктонно-бентосним i планктонним формам водоростей, індикаторам повільнотекучих i стоячих вод, помірним формам за відношенням до температури води, індиферентам за відношенням до солоності і $p H$. В озері Дідове і Горохівці відзначали помітну частку ацидофілів. Більшість видівіндикаторів сапробності представлена $\beta$-мезосапробами, олігосапробами, оліго- $\beta$-мезосапробами.

Зі зростанням вмісту загального азоту частка олігосапробів знижується. В озерах переважає олігодомінантна структура фітопланктону. Зростання вмісту загального азоту зумовлює зниження його вирівненості.

Ключові слова: фітопланктон, озера, водно-болотні угіддя, різноманіття, чинники середовища.

\section{The formation of lakesphytoplankton under the influence of environmental factors}

\author{
Yulia Shelyuk $^{1}$, Olena Zhytova ${ }^{2}$, Natalia Kuryn ${ }^{1}$ \\ ${ }^{1}$ Zhytomyr Ivan Franko State University, Zhytomyr, Ukraine \\ ${ }^{2}$ Zhytomyr National Agroecological University, Zhytomyr, Ukraine \\ Correspondence: Shelyuk_Yulya@ukr.net
}

Abstract. For the first time, phytoplankton studies of the lakes Voronki, Luko, Ostrivske (Rivne region),
Didove and Gorohivka (Zhitomir region) were carried out. Phytoplankton in the water bodies study was
represented by 161 species (165 intraspecific taxa) belonging to 84 genera, 48 families, 28 orders, 13 classes. It
has been established that diatoms and green algae play leading role in the formation phytoplankton of lakes. The
number of species significantly correlates with pH, color and does not depend on area lakes. The low algal flora
of lakes is characterized by a low number of species of genera (65-91\%). A tendency towards an increase in the
role of small-cell centric diatoms with an increase in the phosphorus content of phosphates and total nitrogen
was revealed. The average value of the diatom coefficient was 0.42 .
A moderate dependence of intensity of algae vegetation on water temperature, phosphorus phosphate content
was established.
In the studies lakes, the leading role belongs to the plankton-bentic and planktonic forms of algae, indicators
of slow-flowing and standing waters, moderate forms with respect to water temperature, indifferents with respect
(C) Шелюк Ю., Житова О., Курин H., 2019 
to salinity and $\mathrm{pH}$ with a noticeable proportion of acidohpiles in Didove Lake and Gorokhivka Wetland. Most types of indicators of saprobity are represented by $\beta$-mesosaprobes, oligosaprobes, oligo- $\beta$-mesosaprobes. With an increase in the total nitrogen content, the proportion of oligosaprobes decreases.

Mostly in the lakes, the oligodominant structure of phytoplankton is observed. An increase in concentration of total nitrogen causes a decrease in the Shannon index.

Key words: phytoplankton, lakes, wetlands, diversity, environmental factors.

\section{ВСТУП}

На сьогодні відома низка робіт із проблем дослідження фітопланктону прісноводних озер України $[1,2]$, оскільки вони є невід'ємним елементом природного ландшафту. Дослідники вказують на досить бідний таксономічний склад малих озер у басейні Прип'яті на території Рівненської області (Омит, Ніговище, Нобель, Сомино, Біле та ін.) [3-5]. Водночас досить багатий склад фітопланктону озера Люб'язь, що знаходиться в Національному природному парку «Прип’ять-Стохід» [6]. Порівняльна характеристика фітопланктону природних озер та озер мегаполісів наведена В. I. Щербаком та Н. С. Семенюк [7].

Попри наведені в літературі відомості, актуальним залишається вивчення закономірностей формування структурно-функціональної організації фітопланктону в типологічно різних озерах за дії природних i антропогенних чинників.

Мета роботи - встановити особливості формування структури озерного фітопланктонну, визначити особливості реагування угруповань планктонних водоростей на комплекс природних і антропогенних чинників.

\section{МАТЕРІАЛИ Й МЕТОДИ ДОСЛІДЖЕНЬ}

За період 2010-2019 рр. дослідженнями структурної організації автотрофної ланки різнотипних озерних екосистем були охоплені озера карстового походження 3 різним рівнем трофії - Воронківське, Луковське й Острівське, заболочене озеро постгляціального походження 3 плавами i прилеглими мезотрофними та евтрофними болотами - Дідове, водно-болотне угіддя Горохівка. Було відібрано й опрацьовано 180 альгологічних проб загальновідомими методами [8].

Озеро Воронки (Воронківське) - заповідне урочище місцевого значення, розташоване в північно-західній частині Рівненської області, має довжину 600 м, площу - 21 га. Озеро Луко знаходиться в північно-західній частині Рівненської області. 3 південногот заходу на північний схід має довжину 1 км і $з$ північного заходу на південний схід - близько 800 м, глибину - до 2,5 м. Острівське озеро розташо- ване в північно-західній частині Рівненської області, безстічне. Довжина водойми 2 км, пересічна ширина - 0,7 км, глибина -7 м, площа водного дзеркала - 106,5 га. Дідове озеро займає північно-східну частину гідрологічного заказника загальнодержаного значення «Дідове озеро» (Овруцький район, Житомирська область). Максимальна глибина озера 2 м, площа 294 га. Водно-болотне угіддя Горохівка знаходиться на відстані 1 км на північний захід від села Гладковичі Овруцького району Житомирської області. У напрямку Гладковичі - Кам'янка має зв'язок із річкою Лутень, а за с. Черенещина з'єднується 3 р. Грезля [9].

Гідрохімічний та еколого-токсикологічний аналіз проводили за стандартними методиками [8]. Для аналізу таксономічного складу застосовували класифікаційну систему Algae of Ukraine [10]. Біоіндикаційна оцінка подана 3 використанням монографії [11]. Індекс сапробності вираховували за Пантле-Буком у модифікації Сладечека, інформаційне різноманіття - за індексом Шеннона [8]. Статистична обробка всього масиву даних здійснена з використанням програм Past, Microsoft Excel, STATISTICA 6.0. $\mathrm{y}$ роботі обговорюються лише значимі кореляції $(\mathrm{p}<0,05)$.

\section{РЕЗУЛЬТАТИ ТА ЇХ ОБГОВОРЕННЯ}

Експериментально встановлені гідрофізичні i гідрохімічні параметри озерних екосистем наведено в табл. 1. У досліджуваних озерах виявлено високий вміст нітратного азоту. У їх складі ідентифіковано 161 вид водоростей, представлений 165 внутрішньо-видовими таксонами 3 номенклатурним типом виду включно (в. в. т.), що належали до 84 родів, 48 родин, 28 порядків, 13 класів. Розподіл водоростей за відділами був таким: Cyanoprokaryota - 18 видів (18 в. в. т.), Euglenophyta - 16 (18), Chrysophyta - 10 (10), Xanthophyta - 2 (2), Bacillariophyta - 52 (53), Dinophyta - 9 (10), Cryptophyta - 2 (2), Chlorophyta - 49 (49) i Charophyta - 3 (3). Y флористичному відношенні найбагатше представлені відділи діатомових $(35 \%$ від загальної кількості видів) і зелених (30\%) водоростей. На третьому місці за видовим 
Науковий вісник Східноєвропейського національного університету імені Лесі Українки. Серія: Біологічні науки, 2019, 4 (388)

багатством знаходяться синьозелені (11\%) та евгленові (майже 10\%).

Найбагатшими у флористичному відношенні були озера: Луко - 83 види водоростей планктону (86 в. в. т.), Острівське - 83 види (85 в. в. т.) та Воронки - 66 (68 в. в. т.). У Дідовому озері і Горохівці кількість ідентифікованих видів сягала 28-32 (табл. 2).

Співвідношення таксонів різних відділів в окремих озерах відрізнялося. У Воронківському діатомові за видовим різно-маніттям поступалися зеленим та синьо-зеленим, у Горохівці пропорція зелені - діатомові зберігалася. В озері Луко та Горо-хівці третє місце за багатством складу займали евгленові, у Воронківському і Дідовому - синьозелені, в Острівському участь цих відділів однакова. речовин, про що свідчить зворотний зв'язок прозорості з кольоровістю води $(r=-0,59 ; n=30)$.

Під час дослідження виявлено тенденцію до посилення ролі дрібноклітинних центричних діатомових зі зростанням вмісту фосфору фосфатів, на що вказує збільшення відношення числа видів центричних діатомових до числа пенатних при посиленні евтрофування ( $r=0,77$; $n=30)$. Вплив загального азоту значно слабший $(r=0,26 ; n=30)$. Середнє значення діатомового коефіцієнта сягало 0,42 .

Аналіз показав, що між кількістю видів водоростей планктону та морфометричними, гідрофізичними і гідрохімічними характеристиками озер, в яких були знайдені, відзначена статистична залежність. На видовий склад впливали величина $p H \quad(r=0,76 ; n=30)$

Таблиця 1

Гідрофізичні і гідрохімічні показники води озер (2010-2019 рр.)

\begin{tabular}{|c|c|c|c|c|c|}
\hline \multirow{2}{*}{ Показники } & \multicolumn{5}{|c|}{ Водойми } \\
\hline & Луко & Воронки & Острівське & Дідове & Горохівка \\
\hline Кольоровість, & $\frac{13-48}{28}$ & $\frac{32-54}{40}$ & $\frac{30-62}{38}$ & $\frac{29-60}{48}$ & $\frac{23-78}{55}$ \\
\hline Прозорість, м & $\frac{0,70-1,20}{1,05}$ & $\frac{0,80-1,30}{1,10}$ & $\frac{0,50-1,10}{0,85}$ & $\frac{0,45-0,90}{0,65}$ & $\frac{0,60-1,00}{0,70}$ \\
\hline $\mathrm{pH}$ & $\frac{7,02-9,54}{7,38}$ & $\frac{7,27-8,00}{7,56}$ & $\frac{7,15-8,34}{7,80}$ & $\frac{6,50-7,80}{7,30}$ & $\frac{6,80-7,57}{7,00}$ \\
\hline $\begin{array}{c}\text { Розчинений кисень, } \\
\text { мг } \mathrm{O}_{2} / \text { дм }^{3}\end{array}$ & $\frac{6,04-16,11}{10,83}$ & $\frac{6,00-10,26}{8,80}$ & $\frac{6,60-14,8}{12,20}$ & $\frac{9,0-21,4}{16,3}$ & $\frac{9,30-16,0}{12,00}$ \\
\hline $\begin{array}{c}\text { Окиснюваність } \\
\text { перманганатна, } \\
\text { мг О/дм }{ }^{3}\end{array}$ & $\frac{6,0-8,1}{6,7}$ & $\frac{7,8-9,0}{8,3}$ & $\frac{7,8-13,0}{9,2}$ & $\frac{9,0-21,4}{16,3}$ & $\frac{5,7-21,8}{9,6}$ \\
\hline $\begin{array}{c}\text { Лужність загальна, } \\
\text { ммоль/дм³ }\end{array}$ & $\frac{5,2-6,0}{5,6}$ & $\frac{1,3-2,0}{1,8}$ & $\frac{1,4-2,2}{1,9}$ & $\frac{1,6-2,6}{1,9}$ & $\frac{4,2-5,1}{4,9}$ \\
\hline $\begin{array}{c}\text { Жорсткість } \\
\text { загальна, } \\
\text { ммоль/ дм }\end{array}$ & $\frac{4,10-5,20}{4,56}$ & $\frac{2,60-3,10}{2,80}$ & $\frac{4,12-\frac{-5,40}{4,72}}{4}$ & $\frac{1,2-3,80}{2,20}$ & $\frac{2,8-5,80}{5,32}$ \\
\hline $\begin{array}{c}\text { Залізо загальне, } \\
\text { мг/дм }{ }^{3}\end{array}$ & $\frac{0,18-0,62}{0,40}$ & $\frac{0,05-0,18}{0,10}$ & $\frac{0,16-0,35}{0,27}$ & $\frac{0,26-0,70}{0,38}$ & $\frac{0,17-0,48}{0,31}$ \\
\hline Хлориди, мг/дм³ & $\frac{33,8-64,0}{53,6}$ & $\frac{20,2-33,4}{26,5}$ & $\frac{30,2-60,0}{51,0}$ & $\frac{35,0-62,5}{56,8}$ & $\frac{21,0-62,0}{59,6}$ \\
\hline $\begin{array}{c}\text { Фосфор фосфатів, } \\
\text { мг Р/дм }{ }^{3}\end{array}$ & $\frac{<0,01-0,05}{0,02}$ & $\frac{0,01-0,01}{0,01}$ & $\frac{0,01-0,06}{0,04}$ & $\frac{0,01-0,07}{0,05}$ & $\frac{0,01-0,03}{0,02}$ \\
\hline $\begin{array}{l}\text { Азот амонійний, } \\
\text { мг N/дм }{ }^{3}\end{array}$ & $\frac{0,02-0,68}{0,07}$ & $\frac{0,09-1,60}{0,48}$ & $\frac{0,07-1,40}{0,40}$ & $\frac{0,78-1,58}{1,39}$ & $\frac{1,09-1,27}{1,15}$ \\
\hline $\begin{array}{l}\text { Азот нітритів, } \\
\text { мг N/дм }{ }^{3}\end{array}$ & $\frac{0,001-0,006}{0,004}$ & $\frac{0,008-0,056}{0,011}$ & $\frac{0,001-0,004}{0,002}$ & $\frac{0,008-0,108}{0,021}$ & $\frac{0,001-0,104}{0,021}$ \\
\hline $\begin{array}{l}\text { Азот нітратів, } \\
\text { мг N/дм }{ }^{3}\end{array}$ & $\frac{2,00-3,00}{1,56}$ & $\frac{0,80-2,88}{1,45}$ & $\frac{0,70-2,80}{1,50}$ & $\frac{0,85-4,16}{2,56}$ & $\frac{0,69-7,26}{3,25}$ \\
\hline
\end{tabular}

Примітка. над рискою наведені межі коливань, під рискою - середні значення; «х»-вимірювання не проводилися. 
та кольо-ровість $(r=-0,70 ; n=30)$, але він не залежав від площі озер та рівня загального азоту і фосфору фосфатів. Світловий режим в озерах значною мірою визначається вмістом гуміно-вих

Кластеризація водойм за складом водоростей показала, що найбільша флористична подібність властива карстовим озерам, розташованим на території Рівненської області (Луко, Воронки й Острівське), в окремий кластер винесена Горохівка (рис. 1).

Спільними для всіх озер були тільки 2 види: Cyclotella stelligera (Cleve et Grunow) Van Heurck i Chlamydomonas monadina (Ehrenb) F. Stein. Специфічний комплекс, що складався 3 таксонів рангом нижче роду, які траплялися лише в одній водоймі, формували 95 видів та внутрішньовидових таксонів, що складає $58 \%$ від загального ïx числа. Для альгофлори озер властиве низьке число внутрішньовидових таксонів і значне число одновидових родів (91-65\%).

Середнє значення родових коефіцієнтів змінювалося від 1,27 (Горохівка) до 1,83 (Воронки). За градіснтом зниження $\mathrm{pH}$ озер спостерігалося зменшення величини родового коефіцієнта $(r=0,66 ; n=30)$. Встановлено слабкий непрямий достовірний зв'язок між вмістом загального азоту та родовим коефіцієнтом $(r=-0,14 ; n=30)$.
До видів із частотою трапляння понад $50 \%$ належали: в озері Луко -Trachelomonas volvocina Ehren (52\%), Cyclotella meneghiniana Kütz. (52\%), у Воронківському - Gomphosphaeria aponina Kütz. (51\%), в Острівському - Cyclotella meneghiniana (89\%), C. Stelligera (77\%), Aulacoseira granulata (Ehrenb.) Simonsen (89\%), A. italica (Ehrenb.) Simonsen (77\%), Stephanodiscus hantzschii Grunow (77\%), Nitzschia acicularis (Kütz.) W.Sm.(56\%), Trachelomonas volvocina (77\%), Aphanizomenon flos-aquae (L.) Ralfs (67\%), Chlamydomonas globosa J. Snow (56\%). y Дідовому озері та Горохівці не було виявлено жодного виду з частотою трапляння понад 50\%. Серед індикаторів місцезростань провідну роль відігравали планктонно-бентосні (40-50\%) і планктонні (32-41\%) форми водоростей. За відношенням до текучості вод та насичення їх киснем переважали індикатори повільнотекучих (50-73\%) та стоячих вод (21-50\%). Найбільшу частку індикаторних форм, що віддають перевагу стоячим водам із низьким рівнем аерації, мав фітопланктон Дідового озера. Серед індикаторів температурного режиму домінували помірні форми (56-75\%), крім того, в озерах Дідове, Острівське, Луко була помітною частка холодолюбних видів (6-33\%).

\section{Таксономічний склад озерного фітопланктону (2010-2019 рр.)}

Таблиия 2

\begin{tabular}{|c|c|c|c|c|c|}
\hline Відділи & Луко & Воронки & Острівське & Дідове & Горохівка \\
\hline Cуanoprokaryota & $\frac{8(8)}{9,6}$ & $\frac{14(14)}{21,2}$ & $\frac{10(10)}{12,0}$ & $\frac{7(7)}{21,8}$ & $\frac{2(2)}{7,1}$ \\
\hline Euglenophyta & $\frac{9(10)}{10,9}$ & $\frac{2(2)}{3,0}$ & $\frac{10(12)}{12,0}$ & $\frac{4(5)}{12,5}$ & $\frac{3(3)}{10,7}$ \\
\hline Chrysophyta & $\frac{6(6)}{7,2}$ & $\frac{3(3)}{4,5}$ & $\frac{0(0)}{0,0}$ & $\frac{2(2)}{6,3}$ & $\frac{1(1)}{3,6}$ \\
\hline Xanthophyta & $\frac{0(0)}{0,0}$ & $\frac{1(1)}{1,5}$ & $\frac{1(1)}{1,2}$ & $\frac{0(0)}{0,0}$ & $\frac{0(0)}{0,0}$ \\
\hline Bacillariophyta & $\frac{32(34)}{38,6}$ & $\frac{9(9)}{13,7}$ & $\frac{32(32)}{38,7}$ & $\frac{9(9)}{28,1}$ & $\frac{9(9)}{32,2}$ \\
\hline Dinophyta & $\frac{1(1)}{1,2}$ & $\frac{6(8)}{9,1}$ & $\frac{4(4)}{4,8}$ & $\frac{1(1)}{3,1}$ & $\frac{2(2)}{7,1}$ \\
\hline Cryptophyta & $\frac{1(1)}{1,2}$ & $\frac{2(2)}{3,0}$ & $\frac{2(2)}{2,4}$ & $\frac{2(2)}{6,3}$ & $\frac{2(2)}{7,1}$ \\
\hline Chlorophyta & $\frac{26(26)}{31,3}$ & $\frac{26(26)}{39,5}$ & $\frac{24(24)}{28,9}$ & $\frac{7(7)}{21,9}$ & $\frac{9(9)}{32,2}$ \\
\hline Charophyta & $\underline{0(0)}$ & $\frac{3(3)}{4,5}$ & $\frac{0(0)}{0,0}$ & $\underline{0(0)}$ & $\underline{0(0)}$ \\
\hline Bсього & $\frac{83(86)}{100}$ & $\frac{66(63)}{100}$ & $\frac{83(85)}{100}$ & $\frac{32(33)}{100}$ & $\frac{28(28)}{100}$ \\
\hline
\end{tabular}

Примітка. Над рискою - кількість видових таксонів в абсолютному вираженні, під рискою - те ж саме у \% від загальної кількості видів водоростей, ідентифікованих у кожній водоймі. У дужках наведене число внутрішньовидових таксонів із номенклатурним типом виду включно. 
Науковий вісник Східноєвропейського наиіонального університету імені Лесі Украӥнки. Серія: Біологічні науки, 2019, 4 (388)

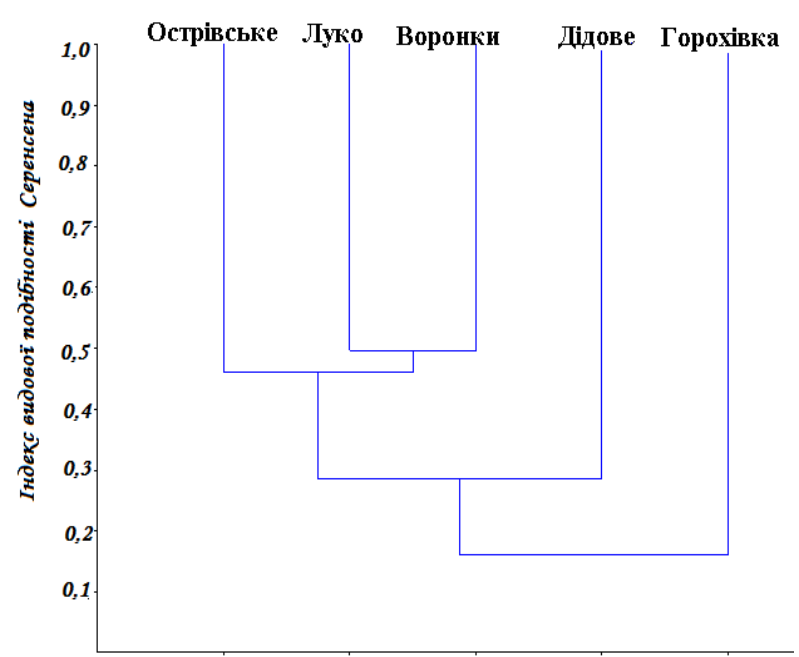

Рис. 1. Дендрограма подібності видового складу озерного фітопланктону

Щодо індикаторів $\mathrm{pH}$ середовища, то найваго-мішу частку в Острівському, Луковському та Воронківському озерах i Горохівці мали інди-черенти (50-60\%), а в Дідовому озері - алкалі-філи (43\%). Водночас в озері Дідове та Горохів-ці помітною була частка ацидофілів (11-14\%). Індикаторів солоності ранжували на групи індиферентів (47-77\%), галофілів (15-33\%) і галофобів (2$20 \%$ ). Основна частка видів-індикаторів сапробності представлена $\beta$-мезоса-пробами $(27,2-33,3 \%)$, олігосапробами $\quad(12,5-16,7 \%)$, оліго- $\quad \beta$-мезосапробами $(11,1-13,3 \%) . \quad$ Зі зростанням вмісту загального азоту частка олігосапробів знижувалася $(r=-0,19 ; n=30)$.

Кількісні параметри розвитку фітопланктону досліджуваних озерних екосистем змінювалися в широких межах. Найвищі середні показники чисельності $\left(13,018-38,865\right.$ тис. кл/дм $\left.{ }^{3}\right)$ та біомаси $\left(1,760-2,13 \Gamma / \mathrm{M}^{3}\right)$ зареєстровані в озерах Острівське, Воронки і Луко (табл. 3).
Підтверджено прямий тісний зв'язок між біомасою озерного фітопланктону і значеннями $p H(r=0,91 ; n=30)$. Помірним він був із температурою води $(r=0,14 ; n=30)$, вмістом фосфору фосфатів $(r=0,16 ; n=30)$, із концентрацією загального азоту - від'ємний $(r=-0,36 ; n=30)$. Кольоровість не визначає формування біомаси фітопланктону $(r=-0,06 ; n=30)$.

В озерах Воронки та Дідовому спільною особливістю було щорічне зростання чисельності i біомаси літнього фітопланктону, а в Луко, Острівському та Горохівці спостерігали зростання цих показників в осінній період (табл. 4).

Домінуючими відділами у формуванні біомаси навесні були діатомові водорості в Острівському озері (36\%) і Горохівці (43\%); зелені - у Луківському (34\%); синьозелені - у Дідовому (96\%) і Воронківському (68\%) озерах. У літній період основну частку біомаси діатомові водорості формували лише в Острівському озері (41\%), синьозелені - у Луковському (53\%), Воронківському (66\%), Дідовому (92\%), зелені у Горохівці (59\%). Восени домінуючими відділами були зелені водорості - в озері Воронки (44\%), діатомові - в Острівському (69\%), синьозелені - в Луківському (51\%), динофітові у Горохівці (39\%).

Чисельність водоростевих клітин досліджуваних озерних екосистем визначали синьозелені водорості: у Луковському озері вони домінували впродовж літа-осені (87-94\%), у Воронківському - навесні та влітку (92-98\%), у Дідовому протягом весни та осені (94-97\%); діатомові - впродовж усіх сезонів (42-46\%) - в Острівському, а зелені - у Горохівці (46-84\%). Аналіз інформаційного різноманіття за індексом Шеннона, розрахованого за біомасою водоростевих клітин, показав, що озерним екосистемам властиве переважання моно- та

Кількісні показники розвитку фітопланктону озерних екосистем

Таблиия 3

\begin{tabular}{|c|c|c|c|c|}
\hline Озера & $N$, тис. кл/дм ${ }^{3}$ & $\boldsymbol{B}, \Gamma / \mathrm{M}^{3}$ & $S$ & $\boldsymbol{H}_{B}$, біт. /Г. \\
\hline Луко & $\frac{0,084-143,948}{13,018 \pm 0,87}$ & $\frac{0,070-14,733}{2,13 \pm 0,36}$ & $\frac{0,90-2,30}{1,61 \pm 0,01}$ & $\frac{0,33-1,46}{1,93 \pm 0,04}$ \\
\hline Воронки & $\frac{0,046-76,343}{15,543 \pm 0,36}$ & $\frac{0,030-4,600}{1,760 \pm 0,36}$ & $\frac{1,04-2,33}{1,58 \pm 0,02}$ & $\frac{0,17-2,30}{1,35 \pm 0,06}$ \\
\hline Острівське & $\frac{4,246-246,600}{38,865 \pm 1,01}$ & $\frac{0,186-17,078}{9,330 \pm 0,92}$ & $\frac{1,150-2,222}{1,810 \pm 0,12}$ & $\frac{2,67-3,78}{3,06 \pm 0,11}$ \\
\hline Дідове & $\frac{0,191-7,210}{1,503 \pm 0,22}$ & $\frac{0,009-0,745}{0,193 \pm 0,03}$ & $\frac{0,75-2,29}{1,51 \pm 0,03}$ & $\frac{0,09-2,21}{0,94 \pm 0,05}$ \\
\hline Горохівка & $\frac{0,008-0,837}{0,261 \pm 0,03}$ & $\frac{0,005-0,232}{0,739 \pm 0,04}$ & $\frac{0,67-2,55}{1,71 \pm 0,01}$ & $\frac{0,27-1,85}{1,36 \pm 0,13}$ \\
\hline
\end{tabular}

Примітка: $N$ - чисельність фітопланктону; $B$ - біомаса, $S$-індекс сапробності, $H_{B}-$ індекс Шеннона. 
Сезонна динаміка кількісних показників розвитку озерного фітопланктону

\begin{tabular}{|c|c|c|c|c|c|c|}
\hline \multirow{2}{*}{ Озера } & \multicolumn{2}{|c|}{ Середня чисельність, млн. кл/дм ${ }^{3}$} & \multicolumn{3}{c|}{ Середня біомаса, г/ $\mathbf{m}^{3}$} \\
\cline { 2 - 7 } & весна & літо & осінь & весна & літо & осінь \\
\hline Луко & $1,037 \pm 0,21$ & $13,524 \pm 1,70$ & $19,146 \pm 1,64$ & $0,607 \pm 0,11$ & $1,441 \pm 0,20$ & $3,554 \pm 0,22$ \\
\hline Воронки & $14,201 \pm 1,12$ & $25,273 \pm 2,46$ & $1,698 \pm 0,12$ & $1,124 \pm 0,17$ & $2,843 \pm 0,30$ & $1,207 \pm 0,11$ \\
\hline Острівське & $10,810 \pm 1,09$ & $35,745 \pm 2,16$ & $45,984 \pm 3,65$ & $4,829 \pm 0,68$ & $8,983 \pm 1,43$ & $11,663 \pm 1,16$ \\
\hline Дідове & $0,002 \pm 0,00$ & $0,039 \pm 0,00$ & $0,001 \pm 0,00$ & $1,130 \pm 0,12$ & $2,008 \pm 0,14$ & $0,214 \pm 0,08$ \\
\hline Горохівка & $0,090 \pm 0,03$ & $0,168 \pm 0,11$ & $0,579 \pm 0,01$ & $0,056 \pm 0,02$ & $0,056 \pm 0,03$ & $0,158 \pm 0,07$ \\
\hline
\end{tabular}

олігодомінантної структури фітопланктону впродовж усіх сезонів (див. табл. 3). Висока вирівненість фітопланктону спостерігалася лише в Острівському озері.

При усередненні величин індексу Шеннона за рангами біомаси залежність між цими показниками апроксимувалася поліноміальною кривою зі зростанням інформаційного різноманіття під час збільшення біомаси фітопланктону (рис. 2).

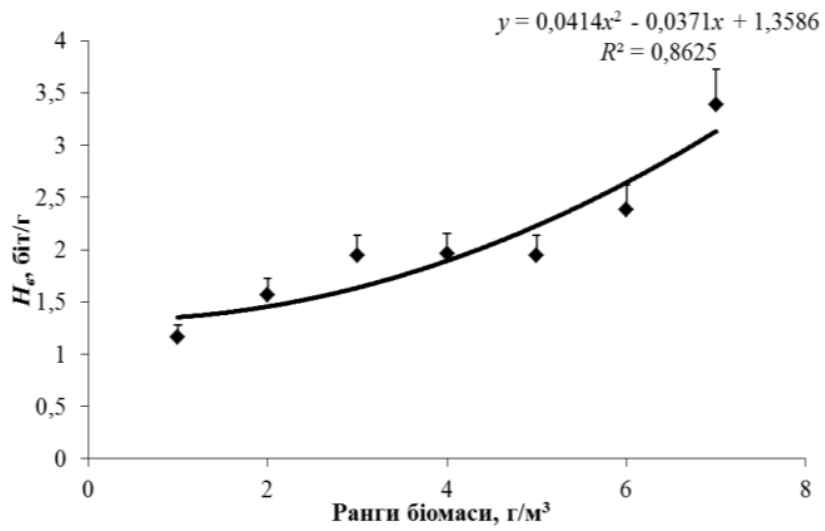

Рис. 2. Зв'язок індексу Шеннона з біомасою озерного фітопланктону

Примітка. По осі абсиис ранги біомаси: $1-<0,1 ; 2-0,1-0,5 ; 3-0,6-1,0 ; 4-1,1-2,0 ; 5-$ $2,1-5,0 ; 6-5,1-10,0 ; 7-10,0-50,02 / \mathrm{M}^{3}$.

Аналіз зв'язку інформаційного різноманіття 3 умістом біогенів показав, що вміст фосфору фосфатів не визначає інформаційне різномуніття фітопланктону, про що свідчить відсутність достовірної залежності між вмістом загального азоту, фосфору фосфатів та індексом Шеннона $H_{B}$ в озерах. Однак на $H_{B}$ помірно впливає вміст загального азоту $(r=-0,34)$. Виявлено тісний зв'язок $H_{B}$ iз $\mathrm{pH}$ води $(r=0,83)$, із кольоровістю він майже відсутній $(r=-0,05)$.

Між біомасою фітопланктону й індексом Шеннона фіксували тісний достовірний зв'язок $(r=0,96)$. Водночас, зміни інформаційного різноманіття не визначаються температурою води $(r=-0,11)$.

Встановлено, що в озерах домінуючий комплекс фітопланктону сформовний значним числом видів, що найчастіше належать до родів Trachelomonas Ehrenb., Peridinium Ehrenb., Chlamydomonas Ehrenb., Crucigeniella Lemmerm., Cyclotella Kütz., Aulacoseira Thw. Y мезо-евтрофних за вмістом фосфору фосфатів Дідовому та Острівському озерах улітку відзначали збільшення числа видів, що формують домінантний комплекс, в оліготрофних i мезотрофних озерах (Луко, Воронки, Горохівка) - помітне зменшення числа видів-домінантів в осінній період, та збагачення в літній не відбувалося.

\section{ВИСНОВКИ}

У формуванні озерного фітопланктону провідну роль відіграють діатомові $(32,3 \%$ від загального списку видів) і зелені $(30,4 \%)$ водорості. Кількість таксонів рангом нижче роду тісно й достовірно корелює 3 величиною $p H$, кольоровістю і не залежить від площі озер.

Встановлена тенденція до посилення ролі дрібноклітинних центричних діатомових зі зростанням вмісту фосфору фосфатів і загального азоту, на що вказує збільшення відношення числа видів центричних діатомових до числа пенатних при посиленні евтрофування.

У досліджуваних озерах провідну роль відіграють планктонно-бентосні (40-50\%) і планктонні (32-41\%) форми водоростей, індикатори повільнотекучих $(50-73 \%)$ та стоячих вод (21-50\%), помірні форми за відношенням до температури води (56-75\%), індиференти за відношенням до солоності (47-77\%) і $\mathrm{pH}$ (50$60 \%)$ із помітною часткою ацидофілів (11-14\%) в озері Дідове та Горохівці. Основна частина видів-індикаторів сапробності представлена $\beta$ мезосапробами $(27,2-33,3 \%)$, олігосапробами $(12,5-16,7 \%)$, оліго- $\beta$-мезосапробами $(11,1-$ $13,3 \%)$. Зі зростанням умісту загального азоту частка олігосапробів знижується. 
Біомасу озерного фітопланктону визначає $p H$ води. Помірною є залежність інтенсивності вегетації водоростей він температури води, вмісту фосфору фосфатів. Кольоровість не чинить помітного впливу на формування біомаси фітопланктону.

У більшості озер переважає олігодомінантна структура фітопланктону. Зростання вмісту загального азоту зумовлює зниження його вирівненості.

\section{ЛIТЕРАТУРА}

1. Щербак, В. И.; Майстрова, Н. В. Структурная характеристика фитопланктона озерных экосистем Шацкого национального природного парка. Наукові праці Поліської ЛНДС «Проблеми екології лісів $i$ лісокористування на Поліссі Украӥни». Волинь: Житомир, 1999, 6, с 84-91.

2. Герасимова, О. В. Матеріали до флори водоростей Дніпровсько-Орільського природного заповідника (Україна). Наукові записки Тернопільського національного педагогічного університету імені В. Гнатюка. Серія: Біологія. Спец. вип. «Гідроекологія»; 2005, 3, с 77-79.

3. Васенко, А. Г; Петренко, О. Н; Климов, А. В; Ильевская, Ю. А; Величко, Г. М и др. Экологическое состояния трансграничных участков рек бассейна Днепра на территории Украины: Программа ПРООН-ГЭФ экол. оздоровления бассейна Днепра, Центр исслед. междунар. развития (IDRC); Академпериодика: Киев, 2002; с 355.
4. Тюх, Ю. Ю; Царенко, О. М; Царенко, П. М. Фіторізноманіття національного природного парку «Синевир» та питання його охорони. Науковий часопис НПУ імені М. П. Драгоманова. Серія: Біологія; 2012, 4, с 3-9.

5. Малахов, Ю. П. Новые данные о разнообразии водорослей Ривненского природного заповедника. Альгология; 2014, 24 (3), с 399-403.

6. Щербак, В. I; Майстрова, Н. В; Морозова, А. О; Семенюк, Н. Є. Національний природний парк «Прип'ять-Стохід». Різноманіття $і$ гідрохімічна характеристика акваландшафтів. Фітосоціоцентр: Київ, 2011; с 164.

7. Щербак, В. І.; Семенюк Н. С. Фітопланктон водойм мегаполіса (на прикладі м. Києва). Український ботанічний журнал; 2011, 68 (1), c 113-212.

8. Арсан, О. М; Давидов, О. А; Дьяченко, Т. М. та ін.; ред. В. Д. Романенко. Методи гідроекологічних досліджень поверхневих вод. ЛОГОС: Київ, 2006; c 8-24.

9. Маринич, О. М. та ін. Географічна еничиклопедія України: $y 3 \mathrm{~m}$. «Українська радянська енциклопедія» ім. М. П. Бажана: Київ, 1989; с 472.

10. Tsarenko, P. M; Wasser, S. P; Nevo, E. Algae of Ukraine: diversity, nomenclature, taxonomy, ecology and geography. Cyanoprocaryota, Euglenophyta, Chrysophyta, Xanthophyta, Raphidophyta, Phaeophyta, Dinophyta, Cryptophyta, Glaucocystophyta, and Rhodophyta. Ganter Verlag: Ruggell, 2006; p 713.

11. Баринова, С. С; Медведева, Л. А; Анисимова, О. В. Биоразнообразие водорослей-индикаторов окружающей среды. PiliesStudio: Тель-Авив, 2006; c 498 . 